\title{
Beyond the Fact/Value Distinction: Ethical Naturalism and the Social Sciences
}

\author{
Philip S. Gorski
}

Published online: 16 October 2013

(C) Springer Science+Business Media New York 2013

Can the social sciences tell us anything about how we ought to live and what makes a good society? The conventional answerthe one most academics are taught in graduate school - is negative. Some philosophers tell us that there is an impassable chasm between the "is" and the "ought", a bright line between "facts" and "values." Some social theorists go even further. They argue that values are just a "cultural" or "social construction", a contingent result of history and power, lacking any objective or rational foundation. ${ }^{2}$

The separationists overstate their case. The realms of fact and value are not so easily or neatly insulated from one another. ${ }^{3}$ What is more, the intermixing of is and ought goes far beyond the well studied problem of "bias." Values inflect facts in much more fundamental and less tractable ways. Often, the facts themselves are "value laden." What is less often noticed, and crucial for the present argument, however,

\footnotetext{
${ }^{1}$ Ayer, A. J. 1947. Language, truth, and logic. London,: V. Gollancz Ltd, Mackie, J. L. 1977. Ethics : inventing right and wrong. Harmondsworth; New York: Penguin, Moore, G. E. 1903. Principia ethica . Cambridge: At the University press, Prior, A. N. 1949. Logic and the basis of ethics. Oxford,: Clarendon Press.

${ }^{2}$ Feyerabend, Paul. 1975. Against method: outline of an anarchistic theory of knowledge. Atlantic Highlands, N.J.: : Humanities Press; Foucault, Michel. 1970. The order of things: an archaeology of the human sciences. London,: Tavistock Publications; Haraway, Donna. 1988. "Situated Knowledges: The Science Question in Feminism and the Privilege of Partial Perspective." Feminist Studies 14:575-599.

${ }^{3}$ Anderson, Elizabeth. 2004. "Uses of Value Judgments in Science: A General Argument, with Lessons from a Case Study of Feminist Research on Divorce." Hypatia 19:1-24. Putnam, Hilary. 2002. The collapse of the fact/value dichotomy and other essays. Cambridge, Mass.: Harvard University Press. Railton, Peter. 1986. "Moral Realism." The Philosophical Review 95:163-207. Searle, John R. 1964. "How to Derive "Ought" From "Is"." The Philosophical Review 73:43-58. Taylor, Charles. 1989. Sources of the self: the making of the modern identity. Cambridge, Mass.: Harvard University Press.
}

\section{P. S. Gorski $(\bowtie)$}

Yale University, 493 College St, New Haven, CT 06520-8265, USA

e-mail: philip.gorski@yale.edu is that values are fact laden. In other words, our values have an experiential basis. And this means that they are in principal open to empirical investigation.

The object of these investigations is a middle kingdom of moral facts, situated somewhere between the realms of fact and value, an independent territory, containing discoverable truths about the good life and the good society. Some theologians and philosophers have long argued for its existence. They refer to themselves as "moral realists." 4 This paper briefly surveys this kingdom, with a particular eye to its size and boundaries.

Moral realism comes in various forms. ${ }^{5}$ The one that will be defended here is a form of ethical naturalism. It presumes that human beings "flourish" under certain conditions and falter under others, much like other living beings. ${ }^{6}$ It further presumes that human beings have evolved to be social animals, whose "well-being" is partly determined by the kind of social order they live in - and not merely by the amount of wealth it generates. ${ }^{7}$

If one accepts an ethical naturalism of this sort, then the social sciences can tell us something about the good life and the good society. And, in fact, scholars in neighboring disciplines have already made some significant strides in this direction. Alas, this has been less often true of sociology, where ethical naturalism has made fewer inroads.

This is ironic, because the path is well-trodden. Almost all of the classical theorists were ethical naturalists, who

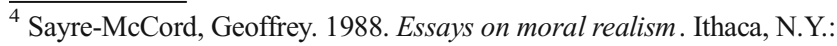
Cornell University Press.

${ }^{5}$ Other forms of moral realism that I will not be defending - or attacking here include: divine command, natural law, and non-naturalism.

${ }^{6}$ Foot, Philippa. 2001. Natural goodness. Oxford; New York: Clarendon, Kraut, Richard. 2007. What is good and why : the ethics of well-being. Cambridge, Mass.: Harvard University Press, Murdoch, Iris. 1971. The sovereignty of good. New York,: Schocken Books.

${ }^{7}$ Dunbar, RIM. 2009. "The social brain hypothesis and its implications for social evolution.” Annals of human biology 36:562-572, Gazzaniga, Michael S. 2005. The ethical brain. New York: Dana Press.
} 
imagined sociology as a "moral science" (Durkheim). The great exception was of course Max Weber. He was a staunch defender of the distinction between facts and values and social science and social policy.

The remainder of this essay is in six parts. Part I will review the two principal arguments for the fact/value distinction. The first is generally attributed to Hume and was subsequently elaborated by the logical positivists during the early $20^{\text {th }}$ century. The second can be traced to Kant and comes to us through Weber. Part II presents some well-known arguments against the fact/value distinction - well known in philosophy at least. Part III critiques arguments in favor of moral relativism advanced by a number of leading social theorists, focusing especially on Steven Lukes. Part IV distinguishes ethical naturalism from other versions of moral realism, and outlines a neo-Aristotelian version premised on the classical vision of eudaimonia. Part $\mathrm{V}$ surveys recent work in this vein by economists, psychologists and political philosophers. Part VI shows that Marx, Tocqueville and Durkheim were all ethical naturalists in this tradition. The conclusion, finally, reflects on the limits of ethical naturalism in the social sciences, thereby offering a partial vindication of Max Weber's contention that directives for social policy cannot be un-problematically derived from the findings of social science, and why.

\section{Two Versions of the Fact/Value Distinction}

The first version of the fact/value distinction is often traced to Hume. In a famous passage of his Treatise of Human Nature (1739), Hume remarks that: "In every system of morality...the author proceeds for some time in the ordinary ways of reasoning... when all of a sudden I am surprised to find, that instead of the usual copulations of propositions, is, and is not, I meet with no proposition that is not connected with an ought, or an ought not. This change is imperceptible; but is however, of the last consequence. For as this ought, or ought not, expresses some new relation or affirmation, "tis necessary that it should be observed and explained; and at the same time that a reason should be given; for what seems altogether inconceivable, how this new relation can be a deduction from others, which are entirely different from it." There is some controversy surroundings the proper interpretation of this passage. ${ }^{8}$ On one influential reading, however, Hume is said to be arguing for a hard distinction between the is and the ought. Some even refer to this argument as "Hume's Law" or "Hume's guillotine", because it sharply and fully severs the realms of fact and value. ${ }^{9}$ When combined with "Hume's

\footnotetext{
${ }^{8}$ MacIntyre, A.C. 1959. "Hume on" is" and" ought". " The Philosophical Review 68:451-468.

${ }^{9}$ Hare, R. M. 1952. The language of morals. Oxford England: Clarendon Press.
}

fork", the claim that we can only have true knowledge about the empirical world, it leads to the conclusion that the concept of "moral knowledge" must be a contradiction-in-terms.

The second version of the fact/value distinction may be traced to Kant's first and second critiques, which were partly an attempt to refute Humean skepticism. Hume was skeptical about the possibility of causal knowledge of the natural world. In his Essay Concerning Human Understanding, recall, Hume argued that we cannot make logically valid inferences about causality based on empirical observations, because we can never observe all instances of a phenomenon. Just because the sun rises each morning does not logically entail that it will do so tomorrow! Kant was not convinced. He believed that the natural sciences had generated causal knowledge. The real problem was to understand how they had done so. The Critique of Pure Reason was his answer. In essence, Kant argues that causal relations are not relations between things as they are "in themselves" (the "noumena") but rather between things as they are given to us in experience (the "phenomena"). Put more plainly, Kant argued that our minds are not just passive receptacles for sensory experience. They structure sensory input in a particular way. In terms of certain "categories" like time and space, for instance. Some of these categories, he argues, are prior to all experience. They are "a priori." Perceptions of causality follow from these a priori categories, especially those of time and space. Thus, the "laws of nature" are ultimately grounded in the structures of human perception, rather than in the nature of "things in themselves." How things really are "in themselves" we cannot know. There are limits to human reason.

Kant was also dismayed by Hume's emotivist approach to ethics and his attendant claim that reason should be "the slave of the passions." Kant hoped to show that our moral duties can be rationally derived and that reason should rule the passions. In the Critique of Practical Reason, Kant therefore begins from the (mostly tacit) premise that all human beings are autonomous rational agents. From this it follows that they are ends in themselves. Our moral duty is therefore to treat ourselves and others as ends, and never as means. Thus, we should never allow our rational wills to be the instrument of our sensual desires. Likewise, we should never use others as a means to our personal ends. The various versions of the "categorical imperative" are all attempts to articulate this basic duty. Perhaps the most famous version is presented in the Groundwork: "Act only according to that maxim whereby you can, at the same time, will that it should become a universal law." It is important to note that Kant's ethics are more procedural than substantive; they give us rules for moral reasoning rather than for moral action.

Note, too, that there is a deep tension between Kant's epistemology and his ethics. His epistemology assumes that the natural world is governed by causal laws. His ethics demands that human action be governed by moral laws. But human beings are embodied creatures; they inhabit both worlds. How can their actions be governed by two different sets of laws? Put 
plainly, how is free will possible in a world of causal determinism? Kant "solves" this problem by appealing to the mysterious, noumenal faculty of "the will", a faculty that somehow transcends but supervenes on nature.

The fact/value distinction enters into modern social science by two principal routes. The first is "logical-positivism", an Anglo-Austrian intellectual movement that had a profound influence on the philosophy of science during the first half of the $20^{\text {th }}$ century. Ludwig Wittgenstein was a member for a time, and Karl Popper was a hanger on. Logical positivism was influenced by Kantian idealism and British empiricism and sought to combine elements of both. From Kant, it took the view that our experience of the world is influenced by the categories of our understanding. For the logical positivists, however, the key "categories" were linguistic ones. And the main job of philosophy was to apply the rules of logic to police our use of language. What logical positivism took from British empiricism is a view of facts as unmediated sensory impressions, and of causal laws as a "constant conjunction" between such impressions. The "falsificationist" methodology of Karl Popper is one fruit of this synthesis. ${ }^{10}$

Another, more relevant in this context, is Rudolf Carnap's famous distinction between three types of judgments: 1) "synthetic", meaning judgments with an empirical element, which can be falsified via observations. 2) "analytic", having to do with the proper definition of concepts; they can be logically falsified. 3) "nonsensical", the category in which moral judgments reside, because they cannot be empirically evaluated or logically analyzed. ${ }^{11}$ On this reading, "facts" are based on unmediated sensory experience as rendered in logically coherent language, while "values" are subjective, emotional responses to the world.

The second route by which the fact/value distinction entered into contemporary social science is via the "methodological" essays of Max Weber. ${ }^{12}$ As is well known, Weber's views were deeply influenced by Kant, but also by Nietzsche and the German Historical School. ${ }^{13}$ Let us begin with Weber's theory of values. Weber rejected Kant's claim that moral duties could be firmly grounded in reason. Indeed, in his view, the ends of our action are ultimately irrational - a matter of pure decision rather than rational deliberation. For example, there is, in his view, no rational reason why we should value truth over beauty

\footnotetext{
${ }^{10}$ Popper, Karl Raimund. 1959. The logic of scientific discovery. New York,: Basic Books.

${ }^{11}$ Carnap, Rudolf. 1967. The logical structure of the world; pseudoproblems in philosophy. Berkeley,: University of California Press.

${ }^{12}$ A more detailed version of the following argument may be found in the concluding essay in Gorski, Philip. 2012a. The Protestant Ethic Revisited. Philadephia: Temple University Press.

${ }^{13}$ Beiser, Frederick C. 2011. The German historicist tradition. Oxford; New York: Oxford University Press, Bürger, Thomas. 1976. Max Weber's theory of concept formation : history, laws, and ideal types. Durham, N.C.: Duke University Press, Sica, Alan. 1988. Weber, irrationality, and social order. Berkeley: University of California Press.
}

or the erotic over the political. Our decision to devote ourselves to one "ultimate value" rather than another, he proposes, is fundamentally arbitrary. To this extent, Weber accepted Nietzsche's nihilism. But only to this extent. While our choice of ends is finally irrational, Weber maintained, we can still try to be as clear as possible about what these ends are and as efficient as possible in pursuing them. To this degree, rationality might still play a role in ethics, namely, qua formal and instrumental rationality.

Weber often portrays our choice of ends as a choice between a finite set of "ultimate values." But where do these "ultimate values" come from? How is the choice set defined? In his famous essay on "Religious Rejections of the World", Weber attempts an answer. There, he distinguishes seven "value spheres" or "life orders" (religious, familial, political, economic, scientific, aesthetic and erotic) and discusses their inner logics and the profound "tensions" between them (between the Sermon the Mount and the demands of nationalism, for instance). He argues that these value spheres have become increasingly "rationalized" (internally) and increasingly "differentiated" (externally) over the last two millennia. The initial impetus for their crystallizion, he proposes, was the appearance of "world-rejecting religions" such as prophetic Judaism and Western Christianity, which posited a metaphysical rupture between a mundane and supramundane realm. This seminal rupture, he argues, was the catalyst for all that follows. Weber thereby suggests that this particular constellation of value spheres, seven in number, is a contingent product of Western history. The implication would seem to be that other world-rejecting religions, such as Hinduism and Buddhism, will have generated other sets of ultimate values. In this way, Weber conjoins the cultural relativism of the Historical School to Kantian proceduralism and Nietzschean nihilism - an uneasy amalgam at best.

Weber's view of "facts" will be more familiar to most readers. It is related to his theory of values. In the social world, unlike the natural world, Weber maintains, values can themselves be causes insofar as they become ends of human action (which is not to say that values as Weber defines them are the sole or even predominant ends). Thus, the social sciences must use hermeneutic methods - "interpretation" (Verstehen). Indeed, Weber argues that an "adequate" explanation of a social phenomenon must be premised on an adequate interpretation of the relevant actions. Moreover - and this is key - an adequate explanation will be fully transitive, both historically and culturally. In Weber's (in)famous phrase, it will be just as compelling to "the Chinaman" as the Westerner.

How so? How does Weber reconcile this claim to factual objectivity with his commitment to cultural relativism? By means of his famous distinction between "value relations" (Wertbezüge) and "value neutrality" (Wertfreiheit). Cultural values will inevitably enter into our choice of research questions. However, they can - and must - be kept out of our research findings. The social and natural sciences cannot 
provide us with any guidance as to how we should live or what sort of society we should prefer, he says, and they should never pretend to do so. But they can help us choose the best means to our own personal or political ends. Achieving them, however, will necessarily involve struggle against those who hold opposing ends. And such struggles can only be resolved through politics, which, for Weber, means conflict.

At first glance, the positivist and interpretivist versions of the fact/value distinction may seem quite different, even opposed. And with regard to their theories of value, they are. Carnap banishes ethics to a realm of "nonsense" ruled by emotion. Weber keeps ethics within the bounds of reason, while diminishing the powers of reason. But there are striking similarities as well. This is perhaps most obvious with respect to their theories of facts. Both Carnap and Weber insist that there is an intransitive realm of fact that is clearly bounded from the influence of value. The similarities also extend to their understanding of values. Both understand values as subjective and relative. In this regard, they are far more radical than either Hume or Kant. Hume still believed that all human beings had shared moral sensibilities. Kant still believed that an autonomous human reason led to universal moral obligations. They were not nihilists. Carnap and Weber were.

Their shared nihilism arose out of a certain form of "moral imaginary." By "moral imaginary", I mean a set of interlinked background assumptions about the interrelationship of nature, self and society that are mostly unarticulated. ${ }^{14}$ Both, to begin, embraced a fully mechanistic and "disenchanted" view of nature, that was shorn of any final purpose or inherent meaning. This was the heritage of Western science, or at least of a certain understanding of it. ${ }^{15}$ Second, both presumed a highly disembedded and clearly bounded view of the self. ${ }^{16}$ They imagined human persons as autonomous "wills" endowed with capacities of self-creation and value-projection. These selves were no longer part of nature in any meaningful sense, indeed, they were selves precisely insofar as they asserted themselves against nature. Thirdly, and finally, both inclined towards a highly atomistic and agonistic view of the social world. They tended to view human societies as aggregations of opposing and conflicting wills that were channeled and contained via markets and states. The crucial point to notice here is that the fact/value distinction presumes, not just a certain understanding of epistemology and ethics but, more than that, a certain ontology as well. It is suspended in a wider web of beliefs. ${ }^{17}$ Does the web hold?

\footnotetext{
$\overline{14}$ Taylor, Charles. 2004. Modern social imaginaries. Durham, N.C.; London: Duke University Press.

15 _. 2007. A secular age. Cambridge, Mass.: Belknap Press of Harvard University Press.

${ }^{16}$ - 1992. Sources of the self : making of the modern identity. Cambridge: Cambridge University Press.

${ }^{17}$ Quine, W. V. and J. S. Ullian. 1970. The web of belief. New York, Random House.
}

\section{Critiques of the Fact/Value Distinction}

Over the last half-century, the fact/value distinction has been criticized again and again by philosophers of the most diverse stripes. Following Elizabeth Anderson, we can divide these critiques into two main sorts: those that focus on how values influence scientific research and those that focus on how facts are related to value commitments. As Anderson rightly emphasizes, a strong version of the fact/value distinction requires, not only that facts be value free, but also that values be fact free.

Let us begin with the right hand side of the equation - with the ways in which values may impinge on facts. Following Weber, most social scientists would willingly acknowledge that value commitments do unavoidably influence the research process in various ways, but not in ways that necessarily influence the research findings. At the broadest level, for example, scientific research presumes a commitment to scientific truth as an "ultimate value." Obviously, someone who does not share this commitment, or has other ultimate commitments - to power or wealth say - is more apt to shade or distort their research findings. ${ }^{18}$

Further, as noted earlier, our values may also influence our choice of research problems. A feminist might be more likely to study gender than a non-feminist, for example, just as a libertarian might be more interested in studying individual rights than a non-libertarian. One obvious implication of this fact - one that seems to have escaped Weber - is that the composition of the academic community will therefore influence the production of facts. ${ }^{19}$

But there are at least two other ways in which values can influence facts, ones that Weber missed. The first follows from so called Duhem-Quine thesis. ${ }^{20}$ The argument is simple, the situation familiar: in the social sciences, it is often difficult to definitively adjudicate between two or more rival explanations given the available evidence. To which Duhem and Quine would simply add that this is true in all sciences all of the time and would still be true even if we had all of the relevant evidence at our disposal. In Quine's phrase, theories are fundamentally "underdetermined" by evidence. Thus, in choosing between them, we must inevitably appeal to other criteria. Often, these will be "epistemic values" concerning the properties of a "good" theory. Scholarly and disciplinary consensus about the correct ordering of these values is unlikely. For example, some sociologists, and most economists, prefer "parsimonious" theories to "complex" ones. Most anthropologists,

\footnotetext{
${ }^{18}$ This is the principal argument for insulating the community of scientific inquiry from the influence of other social fields.

${ }^{19}$ This is probably the best argument for the diversification of university faculties along both demographic and ideological lines.

${ }^{20}$ Duhem, P.M.M. 1991. The Aim and Structure of Physical Theory:(With a foreword by Jules Vuillemin), vol. 13: Princeton University Press, Quine, WV. 1953. "Two Dogmas of Empiricism”, in From a Logical Point of View. Cambridge, MA: Harvard University Press."
} 
and most historians, will have the reverse preferences. What is more, these preferences are not just aesthetic; they are "ontic" as well, that is, they are linked to underlying assumptions about how social reality "objectively" is - simple and uniform, say, or complex and lumpy. For this and other reasons, most philosophers of science now speak of facts as "theory laden." ${ }^{, 21}$ But, of course, there is always the possibility - the probability really that our assessment of rival theories will be influenced by a values-based form of "confirmation bias."

Another more subtle way in which values may influence facts is via the philosophical anthropology that underlies a social science typology. Weber's own fourfold schema of "social action" provides an excellent example of this. Recall his four basic types: affective, traditional, instrumental and value rational. This schema owes a great deal to Kantian ethics. Firstly, and most obviously, in its focus on "actions" as opposed to, say, "character" (Aristotle) or "disposition" (Bourdieu), as the central category. But secondly and relatedly in characterizing conscious actions based on efficient means (instrumental) and appropriate ends (values) as more "rational" than habitual or affective action. No matter how "dispassionately" we employ this typology, it contains certain assumptions about human personhood, and certain valuations of human capacities that are bound to influence our scholarly interpretations. For example, it will almost inevitably lead us to conclude that Protestantism is more rational than Catholicism.

Let us now shift out attention to the left-hand side of the equation: how might facts influence values? One argument, common among philosophers, focuses on "thick ethical concepts" such as "cruel", "brave", "generous", "indifferent.",22 These words violate the logical-positivist claim that one can draw a sharp line between "factual" and "evaluative" statements. Most of these concepts refer to vices and virtues, that is, to negative and positive character traits. When used properly - this is the crucial point - they are both factual and evaluative. They describe something about a person's character; and they contain a moral judgment of that character. Consequently, it is not possible to use them in a morally neutral way. While efforts have been made to disentangle the evaluative and descriptive "dimensions" of thick ethical concepts, ${ }^{23}$ they are generally regarded as failures. ${ }^{24}$

\footnotetext{
$\overline{{ }^{21} \text { Hesse, M.B. }}$ 1974. The structure of scientific inference: Univ of California Press.

${ }^{22}$ Williams, Bernard Arthur Owen. 1985. Ethics and the limits of philosophy. Cambridge, Mass.: Harvard University Press.

${ }^{23}$ Hare, R. M. and Oxford University Press. 1981. "Moral Thinking Its Levels, Method, and Point." Pp. 250 p. Oxford: Oxford University Press,, Mackie, J. L. 1977. Ethics : inventing right and wrong. Harmondsworth; New York: Penguin.

${ }^{24}$ Foot, Philippa. 1978. Virtues and vices and other essays in moral philosophy. Berkeley: University of California Press, Putnam, Hilary. 2002. The collapse of the fact/value dichotomy and other essays. Cambridge, Mass.: Harvard University Press.
}

Can we simply avoid concepts of this sort? As Leo Strauss points out, Weber himself found it difficult to do so. One finds them in the lyrical passages that conclude The Protestant Ethic, for instance: "Specialists without spirit, sensualists without heart, this nullity imagines that it has attained a level of civilization never before imagined." These words are surely not "value-free!" And Weber quickly repents them; however, he does not strike them either. Nor is this the only place where thick ethical concepts creep into Weber's prose. On the contrary, one frequently finds words like "sublime", "bookish", "grand", "unartistic", and "manly", to name but a few. To this degree, Weber was in clear violation of his own methodological dicta. It would appear that thick ethical concepts are difficult to avoid if one believes, as Weber himself certainly did, that the character traits of actors and the collective ethos of groups can sometimes have a significant causal impact on social and historical events.

But perhaps we can do better than Weber; perhaps we can simply expunge thick ethical concepts from our conceptual lexicons. There are least four basic strategies for doing so. One, quite common in the social sciences, is to employ a wholly utilitarian model of the social actor, one that insists that even the most seemingly disinterested acts (e.g., having children or donating to charity) are "really" based on a sort of subtle self-interest, one that can ultimately be defined in crudely utilitarian terms. ${ }^{25}$ Or, more radically still, we can argue that human actors are "really" just the vehicles of other underlying mechanisms, such as "selfish genes" or neurological automatisms. ${ }^{26}$ In this way, we simply deny the causal significance of moral character or even of human persons. A second strategy, more common in the humanities, is to freely employ evaluative terms, but ones drawn from an aestheticized lexicon (e.g., "in/authentic", "un/original", "sublime" and so on.) The third possibility is to postulate some form of all-determining, supra-individual causality, as in strong versions of French "structuralism" (e.g., Althusserian Marxism and Levi-Straussian anthropology) and "post-structuralism" (e.g., Derridean de-construction and Foucauldian genealogy). Or, more radically still, to elaborate a cybernetic or systems theory of society which locates human person outside the boundaries of the "social system" (e.g., Luhmann). ${ }^{27}$

On closer inspection, none of these strategies proves entirely effective for shoring up the fact/value distinction. Terms like

\footnotetext{
${ }^{25}$ Becker, Gary Stanley. 1976. The economic approach to human behavior. Chicago: University of Chicago Press, - - 1981. A treatise on the family. Cambridge, Mass.: Harvard University Press.

${ }^{26}$ Churchland, P.S. 1989. Neurophilosophy: Toward a unified science of the mind-brain: MIT press, Dawkins, Richard. 1978. The selfish gene. New York: Oxford University Press.

${ }^{27}$ Luhmann, Niklas. 1995. Social systems. Stanford, Calif.: Stanford University Press.
} 
"rational" and "self-interested" have an inescapably evaluative undertone. When people fail to calculate their "real" utilities correctly, or mistakenly act against their "better" interests, as they often do in empirical fact, they are held to be acting "irrationally" or "short-sightedly." Likewise, an individual person who "sacrifices" themselves is presumed to be somehow "defective", and their removal from the gene pool a rough sort of natural justice.

The same holds for words like "authentic" or "original." These are clearly evaluative terms in the cultural field. The hyper-structuralist lexicon of Francophile theory also has its own thinly-disguised praise-terms: "resistance", "rupture", "destabilization", "subversion" and so on. The Germanic version is more fatalistic. Thus, Luhmann's prose is laced with cynical jabs at political activists and social movements that in his view - vainly and naively strive to change a "social system" of which they are not really a part. In each instance, assumptions about the possible and the desirable are inextricably entangled.

But the fundamental difficulty with the left-hand side of the fact/value distinction is this: new facts can also lead to new values. We all know this first hand from our own personal experiences. We may seek to implement a particular moral code or ethical value in our lives only to discover that it leads to unhappiness or ill-being for ourselves or for those around us. And this may eventually cause us to change not only our behavior but our values as well. For example, in our salad days, we might believe that the end of life is experiences of physical pleasure. And we might then discover that late night drinking and early morning hangovers are not really so wonderful after all. And we might decide to change our habits and our values in the direction of greater temperance and selfdiscipline. Or we might decide that academic success is the highest value in our lives, only to discover that excessive work leads to social isolation, which in turn undermines our ability to do academic work.

Can the discovery of new scientific facts also lead to new social values? Take the discovery - and it is a genuine discovery - that capitalist markets are a more efficient mechanism for allocating economic inputs and outputs than central planning of the "real existing socialist" sort. One consequence of this discovery was that neoclassical economics and utilitarian ethics exerted an enormous influence on American politics and culture. Of course, one might object - quite rightly in my view - that this influence has itself been excessive, that the virtues of free markets quickly lead to the vices of social inequality, materialism and individualism, if not tempered by other values. The irony here, perhaps, is that the fact/value distinction itself has helped to create this situation by suggesting that neo-liberal economics is value-free and thereby insulating it from moral criticism! In reality, it is an amalgam of facts and values - of genuine discoveries about the market mechanism and ethical propositions about how to maximize individual and collective well-being.

\section{Moral Relativism?}

The fact/value divide is leaky. Values have a way of seeping into facts; and facts have a way of seeping into values. However, most social scientists have only noticed the first sort of leakage, from values to facts; they have been less attentive to the second. As a result of this one-sided assessment, some social scientists have moved towards a strong form of cultural relativism. Once we see that our values are also influenced by facts or, more precisely, experiences, relativism is itself relativized.

Let us consider the case for relativism. Steven Lukes proposes that we distinguish two different sorts of relativism: "cognitive" and "moral." 28 Cognitive relativism encompasses facts as well as values. In its strongest forms, exemplified by "science studies", cognitive relativism implies that theory choice is not simply under determined by evidence but that it is altogether undetermined by evidence. On this reading, exogenous or external factors - "power", "networks", "culture" and so on - are the crucial factors. From this perspective, we have no reason to prefer the physics of Einstein to the magic of the Azande. They are both equally valid.

Lukes is ultimately - and rightly - unpersuaded by cognitive relativism of this sort. But he seeks to defend a form of moral relativism. This kind of relativism, as Lukes defines it, applies only to "norms" or "values." It is seeded through a growing awareness of human cultural diversity. It takes root via reflection on the socio-historical contingency of one's own moral commitments. And it grows out of a sense that cultural and moral diversity are connected and growing. We can respond to this situation in a number of different ways, he says, ranging from a rigid "moral absolutism" at one extreme to an easygoing "absolute relativism" at the other. Lukes situates himself quite close to the relativist pole.

Note, however, that Lukes poses the problem in a way that presages the answer. By drawing a sharp contrast between the "cognitive" and the "moral", he simply re-inscribes the fact/ value distinction. He implies that cognition and morality are two wholly separate domains. They are not; they overlap. Not only because our understanding of morality is intertwined with our understanding of society, but also because our experiences of ill- and well-being contribute to our (provisional) knowledge of the individual and collective good.

So why does Lukes' moral relativism still seem so persuasive to us? In part, because the realms of the cognitive and the moral are not entirely coterminous. Knowledge of good and ill is not the whole of "morality." First, because even a minimally adequate theory of morality must also include a theory of justice of what is required or obligatory as well as what is desirable or admirable. ${ }^{29} \mathrm{~A}$ theory of justice involves complex judgments

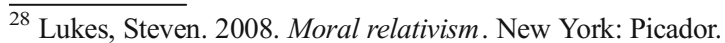

${ }^{29}$ Audi, Robert. 2007. Moral value and human diversity. Oxford; New York: Oxford University Press.
} 
about the balancing and distribution of human and material goods within a society. While judgments about justice may be more or less rational, questions of justice are rarely resolved in a purely rational manner, and it is not even clear that they can be. ${ }^{30}$ And this leaves the door open to self-interest, power and so on.

The second reason - and the more important one for Lukes' argument - is that the moral realm also includes social norms. By "norms", I mean the spoken and unspoken customs and rules that govern everyday interactions. Norms in this sense often strike moderns as "arbitrary." We know that norms vary across space and time and in ways that do not seem to have any effect on human well-being. What difference does it make which side of the road people drive on, so long as it is the same one? What difference does it make whether people use forks or napkins when they eat? However, while social norms may seem arbitrary from the standpoint of second-order reflection, they are generally experienced as obligatory in first-person interactions. Why? Among other reasons, because they are ways of signaling personal respect and maintaining communal solidarity. We may argue about whether social norms are "really" moral obligations. But many norms "feel" obligatory.

This is why moral relativism can feel so persuasive. We see that power often cloaks itself in justice. We understand that many norms are just conventions. And we therefore feel justified in refusing them if they seem unjust or inauthentic. In this context, moral relativism is really an assertion of negative rights - of the right to be left alone, so long as one leaves others alone.

But there are also times when moral relativism feels unpersuasive. For example, when children are involved. No one is really a full-blown moral relativist where the well-being of their own offspring is concerned - not even when other people's offspring are concerned. Good parents want justice done to their children, and they want their children to do justice to others, and they closely monitor their everyday interactions to this end. Good parents also want their children to understand social norms, and when they must be observed. Finally, good parents want their children to understand what conduces to their well-being, and what to their detriment. And if they fail to do these things, they will wonder whether they have been good parents after all.

Similarly, no one is really a full-blown relativist where other cultures are concerned. While they may assign a good deal of cultural variation to the realm of anthropological adiaphora, even the most adamant relativist does not truly believe that it is a matter of moral indifference whether one is born in, say, present day Sierra Leone or Denmark. From behind the "veil of ignorance", they would surely prefer the

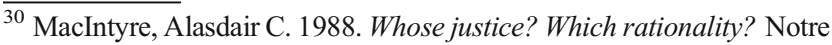
Dame, Ind.: University of Notre Dame Press.
}

latter. In sum, only a fool could sincerely believe that the human and social good are altogether "relative."

Steven Lukes is no fool. In the end, he backs slowly away from full-blown moral relativism. He suggests that there may be a few moral universals. For example, almost all human societies place some restrictions on within-species killing. He also wonders where there might be some ways around the relativist position. Aristotle and Kant strike him as good starting points. And he urges ethnographic investigations of moral life, opening the door to a sociology of morality, perhaps even a social science of ethics, if only a crack. Might we be justified in opening it a little more widely?

\section{Moral Realisms}

Moral realism is the view that there are moral truths that exist independently of human minds and about which human beings can have genuine knowledge. The form of moral realism I wish to defend here is a sort of ethical naturalism. It is "naturalistic" in the sense that it is non-theistic. ${ }^{31}$ And it is "ethical" in the sense that it focuses on the art of living well. For our purposes here, its most important implication is that the sciences, including the social sciences, can help us to live well.

This is not to say that the sciences can do this alone. In determining what it means to live well, they also need help from moral and political philosophy. Living well was a central concern of Greek philosophy, including Aristotle's. Aristotle's ethics were focused on eudaimonia, variously translated as "happiness", "well-being" and "flourishing."32 His politics, meanwhile, was focused on describing the sort of society in which eudaimonia was possible. He saw the ethical and political questions as inseparable. ${ }^{33}$ This is why the Nichomachean Ethics and the Politics were originally written as a single book.

The concept of eudaimonia requires some clarification. The traditional translation was "happiness." Contemporary translators often prefer "well-being" or "flourishing." This is probably because the colloquial understanding of happiness today is so different from Aristotle's. In common English, "happiness" has a utilitarian ring. It conjures a pleasurable emotional state, deriving from a positive sensual experience or social interaction. On a utilitarian logic of this sort, happiness is simply an aggregation of emotional states or experiences. In principle a person with an expected life span of 74 could already be said to have lived a "happy life" long before they

\footnotetext{
${ }^{31}$ Which is not to say that is necessarily a-theistic. On the contrary, it is compatible with certain forms of theism as well as certain forms of materialism.

${ }^{32}$ Kraut, Richard. 1989. Aristotle on the human good. Princeton, N.J.: Princeton University Press.

${ }^{33}$ Lear, Jonathan. 1988. Aristotle : the desire to understand. Cambridge Cambridgeshire; New York: Cambridge University Press.
} 
died, indeed, at whatever point they had experienced pleasure for more than 37 years.

This logic is not Aristotle's logic. Indeed, on his view, the question of whether one has lived a happy life is not settled until after death. Why? Because for Aristotle, happiness is not comprised of an aggregate of sensual experiences but by the overall shape of one's life. A "happy life" is not simply an aggregate of emotional states. It is satisfaction that one has "lived well", that one has lived a life of "virtue", not only in one's own eyes, but in those of one's peers as well.

Aristotle's understanding of "living well" and living "virtuously" also require some clarification. Aristotle argues that all living creatures have a telos, an "end" or "purpose", which is given by their location in the order of nature. On the one hand, human beings are like plants and animals in the sense that they seek to thrive, to live and grow in accordance with their inner constitution. On the other hand, human beings are different from other living beings in the sense that they possess the capacity for speech and reason. In other words, they have "lower" purposes, which they share with animals, and "higher" purposes, which are uniquely human. ${ }^{34}$ To live well, says Aristotle, is to develop and employ one's higher capacities for speech and reason. This is only possible, he thinks, in a polis, where citizens can develop and act on a shared vision of the good life.

The good life, he says, is a virtuous life. In what sense? Certainly not the Victorian one! Aristotelian virtues could hardly be more different than Victorian virtues, which are premised on the notion of restraint - above all, of desire. Aristotelian virtues are premised on the notion of activity especially of skillful activity. They are akin to the embodied skills of an athlete, an artist or a craftsperson, in that they are learned through practice, rather than being imparted through rules. In one famous passage, Aristotle compares the virtuous individual to a skilled archer. An archer always aims for the center of a target. But proper aim depends on a proper understanding of the situation - of the distance to the target, for instance, of the effects of the wind, and so on. It also depends on a proper training of the body, above all of a proper tensioning of the body. Acting virtuously also involves a sort of aiming. If one aims to be generous, for example, one must not give too much - this would be wasteful - nor too little - this would be miserly - but an amount appropriate to the persons and the situation. For Aristotle - and this is a key point justice itself is a kind of virtue, insofar as it involves the skill of weighing and balancing the various and competing goods and ills that will arise out of a particular course of action for oneself and others.

To be sure, Aristotelian ethics has its weaknesses. From the vantage point of the present, for example, we have good reason to reject Aristotle's claim that most people - and all women -

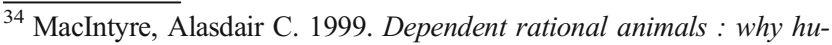
man beings need the virtues. Chicago, Ill.: Open Court.
}

are naturally unfit for politics, and that citizenship should therefore be restricted to propertied males. We might also question his rather narrow conception of the human telos. Surely, we would not want to limit the catalogue of humanity's higher capacities to speech and reason to the exclusion of, say, material and symbolic creativity, as manifested in e.g., engineering and the arts. Nor would we necessarily wish to relegate childrearing to the lower realm of human functioning - and indeed on scientific grounds: nurture of the young by both parents is hardly universal in the animal kingdom, and nurture of the young by non-kin more unusual still. In short, a defensible version of neo-Aristotelian ethics could not accept Aristotle's metaphysics at face value. It would have to be based on a more open-ended and fallibilistic picture of human nature.

That said, a neo-Aristotelian approach also has certain strengths vis-à-vis other ethical systems. Unlike strong versions of social constructionism, for example, it does not require the questionable assumption that human beings are little more than "blank slates." ${ }^{35}$ Rather, in line with evolutionary biology and contemporary neuroscience, it assumes that we are a single species that has certain innate dispositions - a certain degree of pro-sociality for instance ${ }^{36}$ - and shares certain inbuilt capacities - speech and reason among them. Similarly, unlike strong versions of moral relativism, it can account for ethical and cultural pluralism without collapsing into moral subjectivism and cultural relativism. ${ }^{37}$ For example, ethical pluralism can be explained in terms of withinspecies variation. While human beings do share a number of distinctive capacities, these capacities are variably distributed across human individuals. If the art of living well consists in identifying and realizing these capacities, then there will not be any one-size-fits-all model of the good life. The good is itself plural. Ethical naturalism can also evade the trap of cultural relativism by focusing on the social preconditions of human flourishing. Specifically, it will adjudge some social orders to be better than others insofar as they allow individuals enough freedom to discover their capacities and enough resources to realize them.

It must be emphasized, once again, that the sort of ethical naturalism I have in mind here would not - and could not dispense with moral and political philosophy, and for a number of reasons. For one thing, there are certain sorts of moral and political questions which cannot be readily answered in naturalistic terms, such as assisted suicide or just war, questions, in other words, that concern what is right rather than what is good. For another, there are certain questions concerning human

\footnotetext{
${ }^{35}$ Pinker, Steven. 2002. The blank slate : the modern denial of human nature. London: Allen Lane.

${ }^{36}$ Eisenberg, Nancy, Richard A. Fabes, and Tracy L. Spinrad. 2007.

"Prosocial Development." in Handbook of Child Psychology: John Wiley \& Sons, Inc.

${ }^{37}$ Wong, D.B. 2006. Natural moralities: a defense of pluralistic relativism: Oxford University Press, USA.
} 
flourishing which cannot be outsourced to the sciences. The sciences alone cannot easily adjudicate between utilitarian and Aristotelian models of human happiness, for example. There are problems of conceptualization and evaluation here that go beyond the competencies of the sciences.

\section{Ethical Naturalism in the Social Sciences}

Unlike certain forms of philosophical idealism, ethical naturalism does not grant philosophy a monopoly over moral questions either. On the contrary, it opens the possibility that the natural and social sciences can correct and expand our ethical knowledge. As indeed they already have.

Consider the new sub-field of "positive psychology.",38 Traditional psychology mostly concerned itself with the causes of, and remedies for, ill-being. By contrast, positive psychology shifts the focus to understanding and promoting well-being. In his early work, Martin Seligman - one of the co-founders of the movement - defined well-being exclusively in terms of "positive emotion", that is, in fundamentally utilitarian terms. ${ }^{39}$ However, as the title of his most recent book - Flourish - strongly suggests, Seligman has now moved towards a more Aristotelian understanding. ${ }^{40}$ A large body of empirical research - his own and others' - convinced him that positive emotion is only one component of wellbeing. Others include "engagement", "relationships", "meaning" and "accomplishment."

Recent work in the growing sub-field of "happiness economics" also casts doubts on utilitarian orthodoxy. ${ }^{41}$ The pioneer in this area has been Richard Easterlin. In a seminal paper published almost 40 years ago, Easterlin pointed out that the massive increases in material prosperity in the advanced democracies since World War II had not led to a corresponding rise in self-reported levels of individual happiness. ${ }^{42}$ In other words, there was no significant correlation between GDP and happiness. One was rising; the other was flat. Easterlin's finding threatened the normative core of economic theory, namely, utilitarianism, and a decades-long debate ensued. The upshot is as follows: the hedonic returns on increased

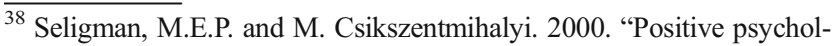
ogy: an introduction." American Psychologist; American Psychologist 55:5.

${ }^{39}$ Seligman, M. 2002. Authentic happiness: Using the new positive psychology to realize your potential for lasting fulfillment: Free Press.

${ }^{40}$ Seligman, M.E.P. 2012. Flourish: A visionary new understanding of happiness and well-being: Free Press.

${ }^{41}$ Frey, B.S. and A. Stutzer. 2001. Happiness and economics: How the economy and institutions affect human well-being: Princeton University Press, Layard, R. 2006. Happiness: Lessons from a new science: Penguin.

${ }^{42}$ Easterlin, R.A. 1974. "Does economic growth improve the human lot?'in (PA David and MW Reder, eds.), Nations and Households in Economic Growth: Essays in Honour of Moses Abramovitz." New York: Academic Press Inc.
}

wealth decrease steadily beyond a certain inflection point which comes at a relatively low level of personal income probably around $\$ 10 \mathrm{k}$ per capita or $\$ 40 \mathrm{k}$ for a household. What is more, these returns are not derived from increased consumption in any generic sense, but from a very specific set of goods, including, better health, more leisure, financial security, and a sense of accomplishment.

Easterlin's argument also contains a political paradox for neoclassical economics. One of its consistent findings is that the relationship between prosperity and well-being is actually weakest in the two countries in the developed world that most closely approach the free-market ideal, namely, the United States and Great Britain. By contrast, the Scandinavian countries tend to outperform expectations. Recent work by Kate Pickett and Richard Wilkinson suggests why this may be: there is a strong and negative correlation between various measures of personal happiness on the one hand and various measures of social inequality on the other. ${ }^{43}$ Why? Because various types of individual and social dysfunction are strongly and positively correlated with inequality: social trust, mental illness, life expectancy, obesity, interpersonal violence, imprisonment rates, drug and alcohol abuse, just to name a few.

Does this mean that social policy should be focused primarily on equalizing incomes, in line with the social ideals of the "Nordic model"? Not necessarily. For much of the last century, progressive politics has focused largely on equalizing and/or maximizing wealth and consumption. But positive psychology and happiness economics suggest that this is the wrong approach, not only because there are decreasing hedonic returns to increased material prosperity, but also because material prosperity is not the only, or even the primary, source of human well-being. This has led Amartya Sen and Martha Nussbaum to propose an alternative approach to social policy, which they call the "capabilities approach." 44 Sen and Nussbaum start from the Aristotelian premise that human beings have certain biologically grounded capabilities, whose realization is constitutive of their well-being. They also emphasize that these capabilities are variably distributed throughout any population. Thus, the crucial aim of social policy must be to create the basic conditions that allow people to discover and develop their own capabilities. The United Nation's Human Development Index is based on the capabilities approach. It includes measures of education, health and wealth. In Frontiers of Justice, Nussbaum has proposed ten capacities that should be protected and nurtured, to wit: life, health, bodily integrity, imagination and thought, emotional expression and attachment, the use of practical reason, affiliation

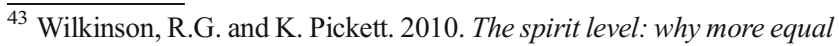
societies almost always do better: Allen Lane.

${ }^{44}$ Nussbaum, Martha Craven. 2006. Frontiers of justice : disability, nationality, species membership. Cambridge, Mass.: The Belknap Press : Harvard University Press, Sen, Amartya Kumar. 1999. Development as freedom. Oxford: Oxford University Press.
} 
with others, protection of other species, play, and political voice. She further emphasizes that this list must be open to debate and revision, based on scientific research and philosophical reflection.

The capabilities approach charts a via media between strong forms of moral relativism and moral universalism. It recognizes that human flourishing can take different forms, because individuals vary in their capacities and dispositions. And it recognizes that flourishing societies may be organized in various ways. But it does not leap from the fact of pluralism to an embrace of relativism. It presumes that there are objective measures of the human good and that some societies will allow for a greater realization of these goods than others.

\section{Ethical Naturalism and Sociology}

Thus far, sociology has not been part of this recent movement towards ethical naturalism in the social sciences. Why? This much is certain: the "founding fathers" are not to be blamed. With the notable exception of Max Weber, they were all ethical naturalists, and of an Aristotelian sort. To this degree, ethical naturalism is a constitutive element of the sociological heritage.

Consider the early Marx. In his 1844 manuscripts, Marx introduced a concept that often causes some consternation amongst his contemporary readers: the concept of "species being" (Gattungswesen). ${ }^{45}$ In part, this consternation is a result of poor translation. Marx's neologism is better rendered as "species essence." When read through an Aristotelian lens, Marx's meaning becomes crystal clear. Like Aristotle, Marx situates human beings within the natural order, and defines human nature in terms of inbuilt capacities. In his "Critique of Hegel", for instance, Marx argues that; "Man is directly a natural being. As a natural being and as a living natural being he is on the one hand endowed with natural powers, vital powers - he is an active natural being."

Further, like Aristotle, he defines humanity's ends in terms of the distinctive capacities that set human beings apart from other creatures. For Marx, however, that telos consists, not in politics, but in economics, in the capacity to reshape nature. In "Alienated Labor", he contends that: "It is true that animals also produce. They build nests and dwellings, like the bee, the beaver, the ant, etc. But they produce only their own immediate needs or those of their young; they produce only when immediate physical need compels them to do so, while man produces even when he is free from physical need and truly produces only in freedom from such need; they produce only themselves, while man reproduces the whole of nature... hence, man also produces in accordance with the laws of beauty." Accordingly, Marx's original vision of communist

\footnotetext{
$\overline{45}$ This mis-translation originates in Marx, Karl, Friedrich Engels, and Robert C. Tucker. 1972. The Marx-Engels reader. New York,: Norton.
}

society was not premised on the goal of material equality but rather on the realization of human capacities. This is quite clear in this famous passage from "The German Ideology": "In communist society...nobody has one exclusive sphere of activity...[which] makes it possible for me...to hunt in the morning, fish in the afternoon, rear cattle in the evening, criticise after dinner, just as I have a mind, without ever becoming hunter, fisherman, herdsman or critic." Of course, in later years, Marx would shift towards a more statist and redistributionist view of communism.

Now consider Durkheim. At first blush, his study of suicide might not seem like a treatise on well-being. Quite the opposite! Today, it is most often seen as a proto-positivistic study of the sociological variables that affect the suicide rates. But read somewhat against the grain, it can also be understood as an empirical study of the social preconditions of human wellbeing. ${ }^{46}$ From this vantage point, each type of suicide that Durkheim identifies can also be understood as the result of a particular social vice - a deficiency or excess of a social virtue. Thus, insufficient "moral regulation" generates "anomic suicide", while excessive moral regulation leads to "fatalistic suicide." A similar analysis can be applied to the other axis of Durkheim's schema. Insufficient "social integration" leads to "egoistic suicide" while excessive integration causes "altruistic suicide." A flourishing society, for Durkheim, is one that achieves a sort of sociological "mean" - a proper balance of moral regulation and social integration.

Marx and Durkheim both offered revisionist versions of the Aristotelian perspective. Marx sought to valorize creative labor as a distinctively human activity, perhaps as the distinctively human activity and therefore as part of humanity's collective telos. Durkheim suggested that there were societal virtues, that a good society was one that balanced the need for individual freedom and autonomy against the need for moral purpose and social connection.

Tocqueville was a bit more of a traditionalist, though he, too, can be seen as a neo-Aristotelian. Like the ancients, he saw participatory self-government as contributing to, even constitutive of, human well-being. The fundamental question, for him, was if and how republican forms of liberty could be preserved and protected in larger-scale polities with a more egalitarian social order. Two things were key. First, connecting self-government to self-interest in order to prompt participation. This is what he meant by "self interest properly understood." Second, expanding the realm of civic participation beyond political society into civil society as a whole. Without some measure of civic virtue, he feared, republican government would devolve into centralized tyranny.

\footnotetext{
${ }^{46}$ For a lengthier version of this interpretation, see: Gorski, Philip. 2012b. "Recovered Goods: Durkheimian Sociology as Virtue Ethics." Pp. 77 104 in The Post-Secular in Question, edited by P. Gorski, D. Kim, J. Torpey, and J. Van Antwerpen. New York: NYU Press.
} 


\section{Reframing the Fact/Value Relationship}

Over the past half-century, philosophers have punctured numerous holes in the fact/value distinction, and sociologists of science have drawn our attention to the many ways in which values can leak into the domain of facts. ${ }^{47}$ Many social theorists have rightly concluded that many facts are value laden. ${ }^{48}$ However, some have wrongly concluded that value-ladenness implies a strong form of cultural relativism - cognitive as well as moral. This is because they have failed to notice that the facts also leak into the domain of values. Values are partly based on experiences, collective as well as individual. And this means that they can be empirically investigated with the tools of the social sciences.

Investigated does not mean adjudicated, much less legislated. The middle kingdom of moral facts should not be imagined as an absolute monarchy ruled by the social sciences, via a "Ministry of Ethical Information." It is perhaps better compared to an ancient city-state, whose civic center is ethical naturalism. The social and behavioral sciences have citizenship rights in this polis, which entitle them to a voice in the forum. But they would be well advised to listen, not only to their cousins in moral and political philosophy, but also to their estranged relatives in religious and theological ethics as well - and not only to them. To philosophers, because the study of human well-being and ill-being raises thorny questions that require conceptual clarity and ongoing reflection. To theologians, because religious traditions are repositories of collective experience that contain "semantic resources"49 that are useful even for non-believers. ${ }^{50}$ Is it reasonable to distinguish between "higher" and "lower" capacities? What is the relationship between first order and second order forms of happiness between positive emotions and life satisfaction say? What role, if any, do sacrifice and suffering play in human well-being?
Empirically oriented social and behavioral scientists are poorly equipped to answer such questions on their own. There is, too, the danger of "intellectualism" if the dialogue is construed too narrowly, a danger, that is, of overvaluing the sorts of goods that intellectuals themselves value. To that degree, scientific studies of well-being cannot escape the jurisdiction of public opinion. Nor can it escape politics. About this, Weber was certainly right, though mostly for the wrong reasons. The problem is not that all values are ultimately subjective and irrational. Rather, it is that human capacities are multiple, variable - and limited. The fact that they are multiple and variable means that even good social orders will privilege some human goods over others. The fact that they are limited means that even well-intentioned people will often conflate their own schedule of goods with that of their fellow citizens, while the ill-intentioned will be loathe to make any compromises in their well-being for the sake of others.

What implications does the collapse of the fact-value distinction have for the research practice of the social sciences? First, it implies that the proper ethos is not "neutrality" so much as open-mindedness. Good social scientists should strive to be aware of their ethical presuppositions and open to revising them in the light of evidence. This is more difficult than it sounds, both personally and intellectually. Our ethics cut deep - much deeper than our political convictions. Revising them can be threatening to our personal identities as well. Second, it implies that any research worth the name has ethical implications of this kind, and that social scientists should strive to be aware of them.

Philip S. Gorski is Professor of Sociology and Co-Director, Center for Comparative Research at Yale University.

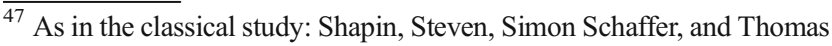
Hobbes. 1985. Leviathan and the air-pump: Hobbes, Boyle, and the experimental life : including a translation of Thomas Hobbes, Dialogus physicus de natura aeris by Simon Schaffer. Princeton, N.J.: Princeton University Press.

${ }^{48}$ Whether all facts are value-laden is an important but controversial issue, which I cannot take up here.

${ }^{49}$ Habermas, Jürgen. 2008. Between naturalism and religion : philosophical essays. Cambridge, UK; Malden, MA: Polity Press.

${ }^{50}$ Badiou, Alain. 2003. Saint Paul : the foundation of universalism. Stanford, Calif.: Stanford University Press.
} 